\title{
Plasma-membrane Phospholipid Unsaturation Affects Expression of the General Amino-acid Permease in Saccharomyces cerevisiae Y185
}

\author{
By JILL CALDERBANK, MICHAEL H. J. KEENAN† AND \\ ANTHONY H. ROSE* \\ Zymology Laboratory, School of Biological Sciences, University of Bath, \\ Bath BA2 7AY, Avon, UK
}

(Received 20 August 1984)

\begin{abstract}
Saccharomyces cerevisiae Y185, enriched in linoleyl residues and incubated for up to $4 \mathrm{~h}$ in derepression buffer, more rapidly acquired general amino-acid permease (GAP) activity, as measured by the rate of accumulation of L-alanine, compared with organisms enriched in oleyl residues. A GAP-less mutant incubated under the same conditions did not acquire further Lalanine-accumulating ability, irrespective of the nature of the fatty-acyl enrichment. During derepression, $K_{\mathrm{T}}$ values for the GAP were virtually identical irrespective of the fatty-acyl enrichment, but $V_{\max }$ values were greater for linoleyl residue-enriched organisms, particularly after $1 \mathrm{~h}$ in derepression buffer. During incubation in derepression buffer, organisms with either fatty-acyl enrichment did not differ in the size of the amino- $\mathrm{N}$ pool, the concentration of $\mathrm{L}$ alanine in that pool, rates of protein synthesis and glucose fermentation, or rate and extent of incorporation of label from $\mathrm{H}_{2}{ }^{32} \mathrm{PO}_{4}^{-}$. Under conditions used to measure rates of L-alanine accumulation, organisms with either enrichment showed no evidence of metabolism of accumulated L-alanine.
\end{abstract}

\section{INTRODUCTION}

A general amino-acid permease (GAP) is synthesized by Saccharomyces cerevisiae when grown in a medium containing a poor nitrogen source, such as proline (Grenson et al., 1970). The GAP is a high-velocity system which is particularly effective in transporting D and L-isomers of basic and neutral amino acids (Rytka, 1975). Saccharomyces cerevisiae synthesizes in addition at least 10 other amino acid-transport systems, each of which is specific for just one or a small number of L-amino acids (Eddy, 1982; Gregory et al., 1982). No specific systems have yet been reported for accumulation of L-alanine (Roon et al., 1975), glycine, L-phenylalanine or Ltryptophan, although each of these amino acids can be transported by the GAP. When grown in a medium containing a good nitrogen source, such as ammonium ions, the GAP is not synthesized (Grenson et al., 1970; Grenson, 1983). However, organisms grown in ammoniacontaining media can be derepressed for the GAP (Woodward \& Cirillo, 1977). Kotyk \& Ríhová (1972) effected derepression by shaking organisms in a glucose solution. Woodward \& Cirillo (1977), however, reported that derepression of the GAP in S. cerevisiae Y185 also required the organisms to be phosphate-sufficient. The present paper reports data showing that the timecourse of appearance of GAP activity, when $S$. cerevisiae Y185 is incubated in glucosecontaining phosphate buffer, differs in organisms with membrane phospholipids enriched in oleyl as compared with linoleyl residues. The study exploited a nutritional technique for changing the lipid composition of the plasma membrane, namely the anaerobically induced

† Present address: AFRC Food Research Institute, Colney Lane, Norwich

Abbreviation: GAP, general amino-acid permease. 
requirement in $S$. cererisiae for a sterol and an unsaturated fatty acid (Andreasen \& Stier, 1953 , 1954), as previously described (Calderbank et al., 1984).

\section{METHODS}

Experimental cultures. Saccharomyces cerevisiae Y185, a haploid strain, was maintained as described by Keenan et al. (1982). The yeast was grown anaerobically using the methods described by Calderbank et al. (1984). Cultures were inoculated and incubated anaerobically, and growth measured as described by Alterthum \& Rose (1973) and Keenan et al. (1982). Organisms were harvested from late exponential-phase cultures $\left(0 \cdot 30-0.32 \mathrm{mg} \mathrm{dry} \mathrm{wt} \mathrm{ml}^{-1}\right)$ as described by Keenan et al. (1982). Mutants of S. cerevisiae Y185 (designated FV1-FV3) lacking the GAP were isolated by a modification of the method of Rytka (1975) as described by Gregory et al. (1982).

Measurement of solute accumulation. Appearance of GAP activity during derepression was followed by measuring L-alanine-accumulating velocity. Harvested organisms were washed twice with citrate buffer $(10 \mathrm{~mm}$; $\mathrm{pH} 4.5 ; 2 \times 25 \mathrm{ml})$ and were resuspended at room temperature to $1.5 \mathrm{mg} \mathrm{dry} \mathrm{wt} \mathrm{ml}^{-1}$ in derepression buffer $\left(\mathrm{KH}_{2} \mathrm{PO}_{4} ; 7.35 \mathrm{~mm}\right.$; pH 4.5; containing $277.5 \mathrm{~mm}$-glucose; Woodward \& Cirillo, 1977). The suspension was placed in a round-bottomed two-arm Quickfit flask $(250 \mathrm{ml}$ capacity), a sample $(15 \mathrm{ml})$ immediately removed, and the remaining suspension incubated at $30^{\circ} \mathrm{C}$ with stirring under a stream of oxygen-free nitrogen gas (Alterthum \& Rose, 1973). Further samples $(15 \mathrm{ml})$ were removed from the suspension with a hypodermic syringe through a Suba seal on a side arm at times indicated up to a maximum of $4 \mathrm{~h}$. Immediately after removal, samples were placed in stoppered tubes that had been flushed with oxygen-free nitrogen gas, and were immersed in a bath containing ice-water. The period of storage never exceeded $5 \mathrm{~min}$. During incubation of organisms in derepression buffer, frequent measurements were made of the $\mathrm{OD}_{600}$ value of the suspension. To determine the dry weight of organisms in the suspension, triplicate portions $(7 \mathrm{ml})$ were removed, centrifuged for $5 \mathrm{~min}$ at $3000 \mathrm{~g}$ and the organisms washed with three $5 \mathrm{ml}$ portions of water. Organisms were then resuspended in $1 \mathrm{ml}$ water, and the suspension transferred to a preweighed metal cup $(16.5 \mathrm{~mm}$ diam.; $21.5 \mathrm{~mm}$ height $)$ and dried to constant weight at $105 \mathrm{C}$ (approx. $72 \mathrm{~h}$ ). Velocity of L-alanine accumulation by organisms was measured at 30 " $\mathrm{C}$ under anaerobic conditions by a modification of the method of Keenan \& Rose (1979). The suspension ( $15 \mathrm{ml}$ ) contained citrate buffer $(10 \mathrm{~mm}: \mathrm{pH} 4.5)$, glucose $(100 \mathrm{~mm})$, organisms $\left(0.5 \mathrm{mg}\right.$ dry $\left.\mathrm{wt}^{-1}\right)$ and L-alanine in the range $25 \mu \mathrm{M} 1.0 \mathrm{mM}$, including both radioactive and non-radioactive amino acid: the specific activity of $\mathrm{L}$-[U${ }^{1+} \mathrm{C}$ jalanine was in the range $22.5225 \mu \mathrm{Ci}(8.33 \mathrm{MBq}) \mathrm{mmol}^{-1}$. The suspension was placed in a round-bottomed Quickfit flask $(100 \mathrm{ml}$ capacity) fitted with two glass-stoppered sampling ports. Velocities of L-alanine accumulation were calculated from plots of the time-course of accumulation for up to $100 \mathrm{~s}$, over which period of time the plots were linear.

The fate of accumulated L-alanine was followed by examining hot-water extracts of organisms for ${ }^{14} \mathrm{C}$ containing compounds. Organisms were allowed to accumulate L-alanine as already described, except that the suspension contained $50 \mu \mathrm{M}-\mathrm{L}$-alanine with a specific activity of $2.25 \mathrm{mCi}(83.25 \mathrm{MBq}) \mathrm{mmol}^{-1}$, and filters with organisms were immersed in $2 \mathrm{ml}$ water at $100{ }^{\circ} \mathrm{C}$ for $10 \mathrm{~min}$. The suspension was then filtered through a membrane filter $(0.45 \mu \mathrm{m}$ pore size; $25 \mathrm{~mm}$ diam.; Millipore), freeze-dried overnight and resuspencled in $50 \mu 1$ water. Ninhydrin-positive compounds in the filtrate were separated by paper chromatography using the solvent system: butan-1-ol water glacial acetic acid $(12: 5: 2$, by vol.). Chromatograms were dried, and examined as described by Keenan et at. (1982).

The ability of organisms undergoing derepression to accumulate $\mathrm{H}_{2} \mathrm{PO}_{4}^{-}$was studied in two ways. To measure the extent of accumulation, harvested organisms were resuspended in derepression buffer in which was incorporated $\mathrm{H}_{2}{ }^{32} \mathrm{PO}_{4}^{-}$at $34 \mu \mathrm{Ci} \mathrm{mmol}^{-1}$. The suspension was incubated as already described under conditions which allow derepression of the GAP. The extent of ${ }^{32} \mathrm{P}$ incorporation was determined at intervals over a $4 \mathrm{~h}$ period. Initial velocities of phosphate accumulation were measured by removing portions from the suspension in derepression buffer at $30 \mathrm{~min}$ intervals. Organisms were harvested by filtration $(0.45 \mu \mathrm{m}$ pore size; $25 \mathrm{~mm}$ diam.; Millipore), washed twice in citrate buffer $(10 \mathrm{~mm} ; \mathrm{pH} 4.5 ; 10 \mathrm{ml})$, and resuspended to $1.5 \mathrm{mg} \mathrm{dry} \mathrm{wt} \mathrm{ml}{ }^{-1}$ in the same buffer. Velocity of $\mathrm{H}_{2}{ }^{32} \mathrm{PO}_{4}^{-}$accumulation was measured in a suspension identical to that described for accumulation of $\mathrm{L}-\left[\mathrm{U}-{ }^{1+} \mathrm{C}\right]$ alanine, with $\mathrm{L}$-alanine being replaced by $74 \mu \mathrm{M}-\mathrm{KH}_{2} \mathrm{PO}_{4}$ and the suspension containing $13.60 \mu \mathrm{Ci} \mu \mathrm{mol}^{-1}$ as $\mathrm{H}_{2}{ }^{32} \mathrm{PO}_{4}^{-}$.

Analytical methods. The size of the total amino- $\mathrm{N}$ pool in organisms undergoing derepression was determined by measuring the concentration of ninhydrin-positive compounds in hot-water extracts. Duplicate portions $(5 \mathrm{ml})$ of

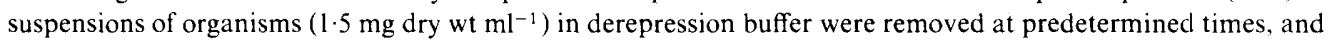
the organisms separated by centrifugation for $2 \mathrm{~min}$ at $3000 \mathrm{~g}$ at room temperature $\left(18-22^{\circ} \mathrm{C}\right)$. Supernatant liquids were discarded and organisms washed twice with portions $(2 \mathrm{ml})$ of water. Washed organisms were suspended in $4 \mathrm{ml}$ water at $100^{\circ} \mathrm{C}$ and suspensions immersed in a bath of boiling water for $5 \mathrm{~min}$. The suspensions were then 
filtered through a membrane filter $(0.45 \mu \mathrm{m}$ pore size; $25 \mathrm{~mm}$ diam.; Sartorius $)$ and filters washed twice with $2 \mathrm{ml}$ portions of water at $100^{\circ} \mathrm{C}$. The combined filtrates were made up to $10 \mathrm{ml}$ and stored at $-20{ }^{\circ} \mathrm{C}$. Total ninhydrinpositive compounds in extracts were assayed by the method of Harris \& Parsons (1958), using L-alanine as the standard. Concentrations of $\mathrm{L}$-alanine in hot-water extracts of organisms were determined by measuring the rate of formation of NADH when extracts were incubated with L-alanine dehydrogenase and $\mathrm{NAD}^{+}$(Williamson, 1974).

Suspensions of organisms ( $300 \mathrm{mg}$ dry wt) in derepression buffer $(200 \mathrm{ml})$ that were to be analysed for lipids were supplemented $15 \mathrm{~min}$ before harvesting with a solution $(2 \mathrm{ml})$ containing $10 \mathrm{mg}$ each of cycloheximide and chloramphenicol. After filtration, as already described, organisms were washed twice on the filter with citrate buffer (10 mM; pH 4.5), and lipid extracted by a modification of the Folch et al. (1957) and Watson \& Rose (1980) procedures. Fatty-acid methyl esters were analysed by GLC on a glass column $(1.5 \mathrm{~m})$ containing $10 \% \mathrm{~S} 2330$ on 100-120 mesh Chromosorb W-AW. The column was used at $170^{\circ} \mathrm{C}$ with the carrier gas $\left(\mathrm{N}_{2}\right)$ flow rate $30 \mathrm{ml} \mathrm{min}-1$, and the detector at $270^{\circ} \mathrm{C}$. Percentage fatty-acid compositions were calculated using a Pye Unicam CDPI computing integrator.

Keto-acid concentrations in suspensions of organisms accumulating $L$-alanine were determined by the method of Woodward \& Cirillo (1977), using L-alanine and pyruvate as standards. Concentrations of volatile compounds derived from L-alanine were determined from the differences between initial radioactive counts included in incubation mixtures and total counts recovered from organisms and filtrates.

Measurement of rates of protein synthesis. These were determined by a modification of the dual labelling procedure of Elliott \& McLaughlin (1978). Organisms (90 mg dry wt) were suspended in derepression buffer $(60 \mathrm{ml})$ containing $0.25 \mu \mathrm{M}-\mathrm{L}$-histidine (including $5 \cdot 0 \mu \mathrm{Ci} \mathrm{L}-\left[\mathrm{U}-{ }^{1+} \mathrm{C}\right]$ histidine). At intervals during derepression of the GAP, portions $(12 \mathrm{ml})$ of suspension were removed and incubated at $30^{\circ} \mathrm{C}$ for $10 \mathrm{~min}$ with a ${ }^{3} \mathrm{H}$-labelled mixture of L-amino acids. The ${ }^{3} \mathrm{H}:{ }^{14} \mathrm{C}$ c.p.m. ratio in extracted and precipitated protein was a measure of the rate of protein synthesis.

Fermentation rate. The ability of organisms to ferment glucose was measured at $30^{\circ} \mathrm{C}$ in a Gilson single-valve differential respirometer as described by Umbreit et al. (1964).

Viability measurements. Viability of yeast populations was measured by staining with methylene blue (Fink \& Kühles, 1933). A portion $(0.5 \mathrm{ml})$ of suspension in derepression buffer was mixed with an equal volume of methylene blue solution $(0.01 \%, \mathrm{w} / \mathrm{v}$, in $2 \%, \mathrm{w} / \mathrm{v}$, sodium citrate). After 5 min incubation at room temperature, wet preparations were examined on haemocytometer slides, and the numbers of live and dead cells established in a population of at least 500 organisms.

Chemicals. All chemicals used were Analar grade or of the highest purity available commercially. Ergosterol, oleic acid ( $\Delta^{9}$ cis-octadecenoic acid), linoleic acid ( $\Delta^{9.12}$ cis, cis-octadecadienoic acid) and $\mathrm{L}$-alanine dehydrogenase were purchased from Sigma. Cycloheximide and chloramphenicol were obtained from BDH and $\mathrm{L}-\left[\mathrm{U}-{ }^{-1+} \mathrm{C}\right]$ alanine from Amersham.

\section{RESULTS}

Growth of organisms and incorporation of exogenously supplied fatty acids into cell phospholipids

Organisms grew anaerobically at the same rate (generation time $1.7 \mathrm{~h}$ ) in the presence of oleic or linoleic acid. Those grown in the presence of oleic acid incorporated $\mathrm{C}_{18: 1}$ residues into their phospholipids to the extent of $69 \%$ of the total fatty-acyl residue content, while those grown in medium containing linoleic acid contained $\mathrm{C}_{18: 2}$ residues to the extent of $51 \%$ of the total phospholipid fatty-acyl content (Calderbank et al., 1984).

\section{Effect of phospholipid fatty-acyl unsaturation on the time-course of derepression of the GAP}

When organisms enriched in either oleyl or linoleyl residues were suspended in derepression buffer, the ability to accumulate L-alanine rapidly increased from a very low value to reach a peak after $1.5-2.0 \mathrm{~h}$ (Fig. 1). The rate of increase in the velocity of $\mathrm{L}$-alanine accumulation was greater in organisms enriched in linoleyl rather than oleyl residues. After about $2.0 \mathrm{~h}$ incubation, the ability to accumulate L-alanine declined in both types of organism (Fig. 1).

Woolf-Hofstee plots (Hofstee, 1959) for accumulation of L-alanine by organisms at zero time in derepression buffer were slightly concave, but did not differ significantly for organisms enriched in oleyl as compared with linoleyl residues (Fig. $2 a$ ). After $1.0 \mathrm{~h}$ incubation, the plots were more concave, and differed for organisms enriched in each residue (Fig. $2 b$ ). On further incubation, Woolf-Hofstee plots became progressively similar in shape and, after $2.0 \mathrm{~h}$, were 


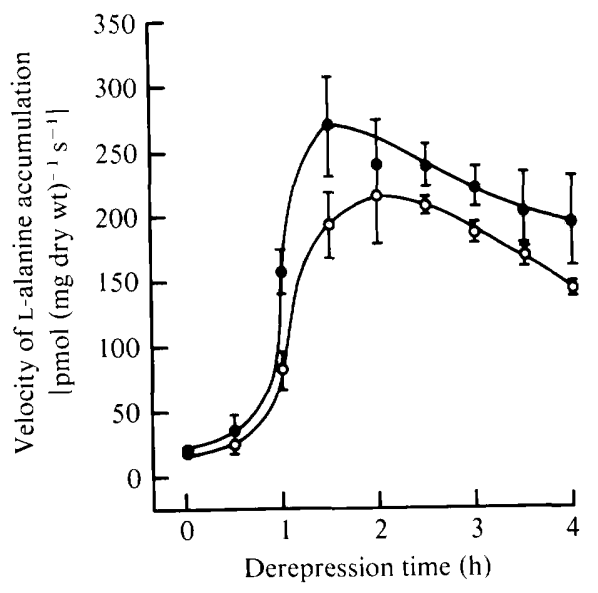

Fig. 1. Time-course of derepression of L-alanine-accumulating ability in $S$. cerevisiae Y185 with phospholipids enriched in oleyl $(O)$ or linoleyl $(O)$ residues. The concentration of L-alanine in the suspension used to measure the velocity of accumulation was $50 \mu \mathrm{M}$. Each value quoted is the average of a minimum of four independent determinations. Vertical bars indicate standard deviations.

superimposable (Fig. $2 c, d$ ). Apparent values for $K_{\mathrm{T}}$ and $V_{\max }$ for the GAP (high-affinity system) and the low-affinity system were determined by computer-aided regression analysis assuming that both systems were represented by two straight lines on Lineweaver-Burke plots, each line being described by four data points. Independent $K_{\mathrm{T}}$ and $V_{\max }$ values were obtained by applying the Neal (1972) correction to the apparent values, assuming that both systems obeyed Michaelis-Menten kinetics. Values for $K_{\mathrm{T}}$ of the GAP during derepression in organisms enriched in oleyl or linoleyl residues were similar, while $V_{\max }$ values were lower in oleyl residueenriched rather than linoleyl residue enriched organisms, particularly during the early stages of derepression (Table 1). At zero time, values for $K_{\mathrm{T}}$ for the low-affinity system were high, but they gradually declined during derepression. Values for $V_{\max }$ for this system initially increased during derepression but thereafter declined. During incubation in derepression buffer for $2.0 \mathrm{~h}$, the apparent concentration of organisms as measured by optical density determinations increased from 1.3 to $2.0 \mathrm{mg}$ dry wt $\mathrm{ml}^{-1}$, irrespective of the nature of the fatty-acyl enrichment. This increase was confirmed by dry wt measurements. Populations of organisms enriched in oleyl or linoleyl residues maintained a viability of over $90 \%$ when incubated in derepression buffer for up to $1.5 \mathrm{~h}$, but thereafter viability slowly declined and, after $4.0 \mathrm{~h}$ incubation, was $85 \%$ in suspensions of organisms enriched in oleyl residues and $74 \%$ with those enriched in linoleyl residues. For up to $2.0 \mathrm{~h}$ incubation in derepression buffer, there was very little (maxirnum of $5 \%$ of the content of any one residue) alteration in the fatty-acyl composition of phospholipids in organisms with either fatty-acyl enrichment. When a GAP-less mutant (FV 3) was incubated in derepression buffer, there was no increase in the low L-alanine-accumulating velocity [approx. $17 \mathrm{pmol}(\mathrm{mg} \text { dry wt })^{-1} \mathrm{~s}^{-1}$ ] over a period of $4.0 \mathrm{~h}$ with organisms enriched in either fatty-acyl residue. The viability of populations of the mutant enriched in either residue remained at more than $90 \%$ over the $4.0 \mathrm{~h}$ period of incubation. Woolf-Hofstee plots for accumulation of Lalanine by this mutant at zero time and after $2.0 \mathrm{~h}$ derepression were linear. Moreover these plots were identical and the $K_{\mathrm{T}}$ and $V_{\max }$ values for the transport system were in the same range as those for the low-affinity L-alanine system of wild-type organisms at zero time.

The size of the amino- $\mathrm{N}$ pool declined during incubation of organisms in derepression buffer for up to $4.0 \mathrm{~h}$ but to the same extent [from 4.5 to $1.6 \mu \mathrm{g} \alpha-\mathrm{NH}_{2} \mathrm{~N}$ (mg dry wt) ${ }^{-1}$ ] in organisms enriched in oleyl or linoleyl residues. The concentration of L-alanine in the amino- $\mathrm{N}$ pool of organisms enriched in either residue also declined during incubation in derepression buffer over a $2 \mathrm{~h}$ period but at the same rate in organisms enriched in either residue $[10 \cdot 3-3 \cdot 2 \mathrm{nmol}(\mathrm{mg}$ dry 

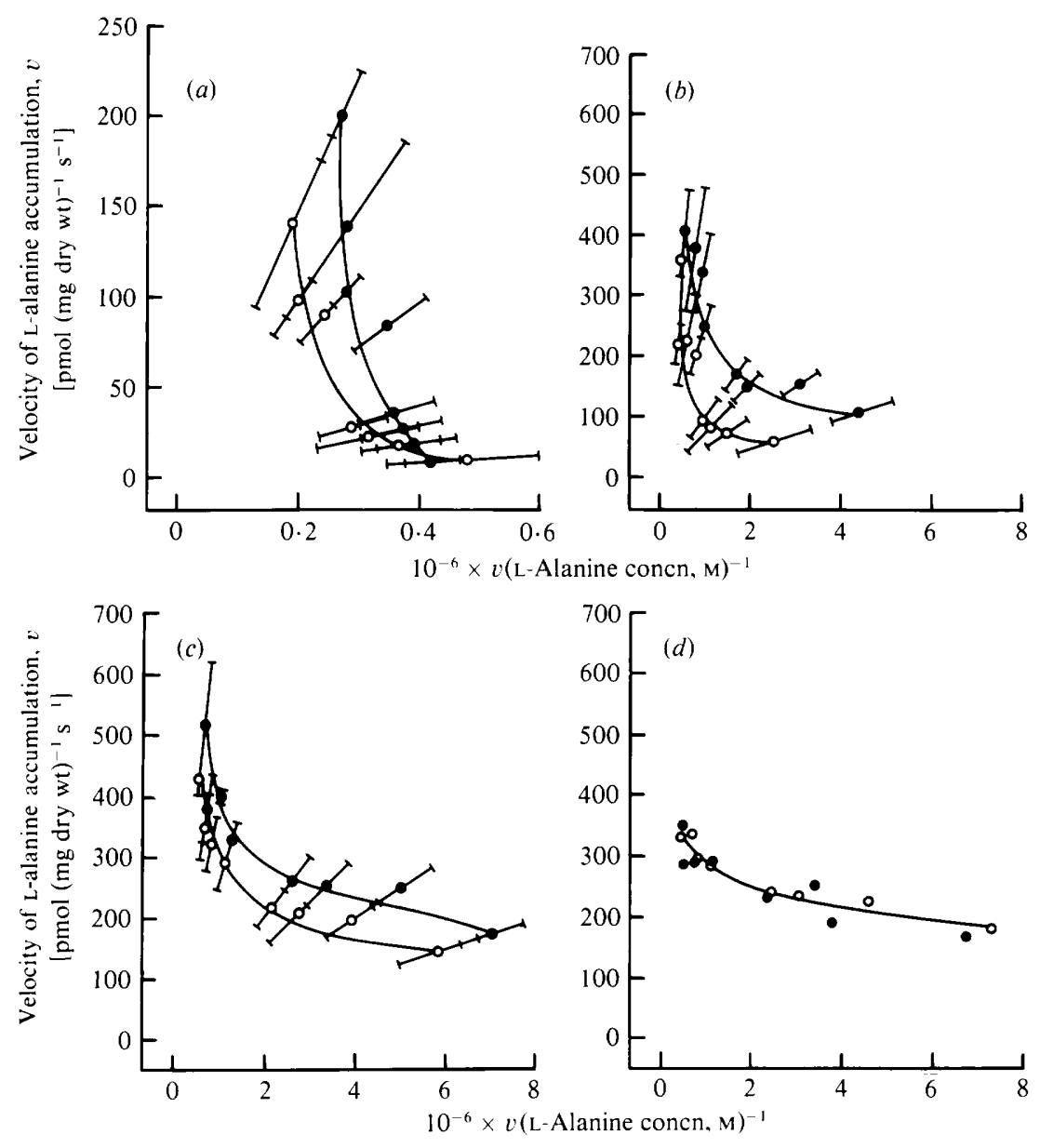

Fig. 2. Woolf-Hofstee plots for accumulation of L-alanine by $S$. cerevisiae $Y 185$ enriched in oleyl (O) or linoleyl (O) residues following incubation in derepression buffer for $0 \mathrm{~h}(a), 1.0 \mathrm{~h}(b), 1.5 \mathrm{~h}(c)$ and $2.0 \mathrm{~h}$ (d). Each value quoted is the average of a minimum of four independent determinations. Bars indicate standard deviations, which are not indicated on $(d)$, where the curves are superimposable.

$w t)^{-1}$ in organisms enriched in oleyl residues, and 11.8-4.6 nmol (mg dry wt $)^{-1}$ with organisms enriched in linoleyl residues]. Autoradiograms of extracts of organisms that had been incubated in derepression buffer for up to $2.0 \mathrm{~h}$, and then allowed to accumulate $\mathrm{L}-\left[\mathrm{U}-{ }^{14} \mathrm{C}\right]$ alanine for up to $100 \mathrm{~s}$, revealed only one spot which had an $R_{F}$ value identical with that of a simultaneously run standard of L-alanine. Evidence that transamination of L-alanine had not occurred came from the failure to detect keto acids in suspensions allowed to accumulate L-alanine for up to $100 \mathrm{~s}$. Rates of protein synthesis in organisms with either enrichment suspended in derepression buffer, as judged by the ${ }^{3} \mathrm{H}:{ }^{14} \mathrm{C}$ c.p.m. ratio, were virtually identical in organisms after $1 \cdot 0,1 \cdot 5$ and $2.0 \mathrm{~h}$. The ratio fell over this period from a value of around 0.58 to 0.45 . Including cycloheximide $\left(10 \mu \mathrm{g} \mathrm{ml}^{-1}\right)$ in derepression buffer completely prevented expression of the GAP, and caused a decay in the low L-alanine-accumulating velocity present at zero time at a rate which was faster in organisms enriched in linoleyl rather than oleyl residues. The presence of cycloheximide in derepression buffer caused a decline in the viability of populations enriched in either fatty-acyl residue after $1.0 \mathrm{~h}$ incubation.

No evidence was obtained for differences in rates of utilization of components of the derepression buffer by differently enriched organisms. Rates of glucose fermentation by 
Table 1. $K_{T}$ and $V_{\max }$ calues for L-alanine accumulation by Saccharomyces cerevisiae Y185 enriched in oleyl or linoleyl residues following incubation in derepression buffer

Units for $K_{1}$ and $V_{\mathrm{max}}$ values are $\mu \mathrm{m}$ and $\mathrm{pmol}(\mathrm{mg} \mathrm{dry} w \mathrm{t})^{-1} \mathrm{~s}^{-1}$, respectively.

Kinetic constants for organisms enriched in:

\begin{tabular}{|c|c|c|c|c|c|c|c|c|}
\hline \multirow{3}{*}{$\begin{array}{l}\text { Time of incubation } \\
\text { in derepression } \\
\text { buffer } \\
\text { (h) }\end{array}$} & \multicolumn{4}{|c|}{ Oleyl residues } & \multicolumn{4}{|c|}{ Linoleyl residues } \\
\hline & \multicolumn{2}{|c|}{$\begin{array}{l}\text { High-affinity system } \\
\text { (GAP) }\end{array}$} & \multicolumn{2}{|c|}{ Low-affinity system } & \multicolumn{2}{|c|}{$\begin{array}{c}\text { High-affinity system } \\
\text { (GAP) }\end{array}$} & \multicolumn{2}{|c|}{ Low-affinity system } \\
\hline & $K_{\mathrm{T}}$ & $V_{\max }$ & $K_{\mathrm{T}}$ & $V_{\max }$ & $K_{\mathrm{T}}$ & $V_{\max }$ & $\boldsymbol{K}_{\mathrm{T}}$ & $V_{\max }$ \\
\hline 0.0 & 40 & 12 & 893 & 282 & 51 & 2 & 1146 & 466 \\
\hline $1 \cdot 0$ & 15 & 75 & 408 & 380 & 18 & 165 & 563 & 527 \\
\hline 1.5 & 19 & 238 & 361 & 275 & 20 & 300 & 432 & 330 \\
\hline $2 \cdot 0$ & 11 & 239 & 185 & 129 & 19 & 299 & 334 & 41 \\
\hline
\end{tabular}

organisms enriched in either residue and suspended in derepression buffer were virtually identical over a $2.0 \mathrm{~h}$ incubation period. The value declined from around $0.33 \mu \mathrm{mol}$ (mg dry $\mathrm{wt})^{-1} \mathrm{~min}^{-1}$ at zero time to about $0 \cdot 15 \mu \mathrm{mol}(\mathrm{mg} \text { dry } \mathrm{wt})^{-1} \mathrm{~min}^{-1}$ after $2.0 \mathrm{~h}$. Moreover, differently enriched organisms accumulated ${ }^{32} \mathrm{P}$ to virtually the same extent over a $4.0 \mathrm{~h}$ incubation period in derepression buffer. The content of $\mathrm{H}_{2} \mathrm{PO}_{4}^{-}$equivalent increased up to about $2.0 \mathrm{~h}$ and thereafter remained constant at about $70 \mathrm{nmol}(\mathrm{mg} \mathrm{dry} \mathrm{wt})^{-1}$. Initial velocities of $\mathrm{H}_{2} \mathrm{PO}_{4}^{-}$accumulation, measured at intervals over a $2.0 \mathrm{~h}$ incubation period, were also the same for differently enriched organisms, decreasing from about $6.5 \mathrm{pmol}(\mathrm{mg} \text { dry } \mathrm{wt})^{-1} \mathrm{~s}^{-1}$ at zero time to approximately $2 \cdot 3 \mathrm{pmol}(\mathrm{mg} \text { dry } \mathrm{wt})^{-1} \mathrm{~s}^{-1}$ after $2 \cdot 0 \mathrm{~h}$ incubation.

\section{DISCUSSION}

Before being able to conclude unequivocally that the transiently greater rate at which the GAP was derepressed was attributable to enrichment of plasma-membrane phospholipids with linoleyl as compared with oleyl residues, it was necessary to show that the effect could not be attributed to other differences in cell physiology. Inhibition by cycloheximide indicated that protein synthesis was necessary for derepression. However, it was evident that the rates of protein synthesis were the same in the differently enriched organisms. Furthermore, the possibility that our data reveal a differential release from transinhibition (Eddy, 1982) of an already existing GAP can be discounted because of the absence of any differences in the size of the intracellular amino- $\mathrm{N}$ pool or of the concentration of L-alanine in this pool. All evidence points to the conclusion that measurements were made of velocities of L-alanine accumulation in the absence of metabolism of this amino acid. Autoradiograms indicated that L-alanine was the only radioactive compound detectable in organisms, added to which no evidence was obtained for action of transaminases on accumulated L-alanine. During derepression, no evidence was obtained for marked or differential changes in the fatty-acyl composition of phospholipids in organisms. Differences in velocities of uptake and extent of accumulation of components of the derepression buffer can also be discounted since virtually identical velocities were obtained for glucose fermentation, initial rate of $\mathrm{H}_{2} \mathrm{PO}_{4}$ accumulation and extent of incorporation of ${ }^{32} \mathrm{P}$ from $\mathrm{H}_{2}{ }^{32} \mathrm{PO}_{4}^{-}$.

L-Alanine was selected for following derepression of the GAP since it is generally believed that it is one of the few amino acids to be transported into $S$. cerevisiae predominantly if not exclusively by the GAP. Justification for this choice came from the discovery that the ability to accumulate L-alanine did not increase when a GAP-less mutant was incubated in derepression buffer. There is a need, however, to explain the small but significant L-alanine-accumulating ability in organisms grown in ammonia-containing media. Woolf-Hofstee plots for L-alanine accumulation by wild-type organisms at zero time of derepression were slightly concave, 
suggesting the presence of two systems capable of transporting this amino acid. However, the $V_{\max }$ value for the high-affinity system at this time was very low, which suggests that the contribution of this very small GAP activity in transporting L-alanine was minimal. Significantly, the GAP-less mutant did not possess this system. A low-affinity system was detected in both wild-type organisms and the GAP-less mutant suggesting that this system was not the GAP. Grenson et al. (1970) reported a very small L-alanine-accumulating ability in $S$. cererisiae $\Sigma 12786$ grown in the presence of ammonium ions, although Roon et al. (1975) were unable to do so using the same strain and a similar ammonia-containing growth medium. It is worth noting that rates of L-alanine accumulation in ammonia-grown organisms by the lowaffinity system reported in the present paper were comparable to those reported for other specific amino acid-accumulating systems in S. cerevisiae (Gregory et al., 1982). An explanation for the decrease in $K_{\mathrm{T}}$ value of the low-affinity system during incubation of organisms in derepression buffer is not immediately apparent. However, the simultaneous decrease in $V_{\max }$ value could have been the result of amino acids produced by turnover of the proteins of this system being preferentially channelled into synthesis of proteins of the more efficient GAP system.

The greater $V_{\max }$ but nearly identical $K_{\mathrm{T}}$ values for the GAP in organisms enriched in linoleyl rather than oleyl residues, following derepression (after $1 \cdot 5-2.0 \mathrm{~h}$ ), can probably be attributed to a greater membrane fluidity in the immediate environment of one or more of the GAP proteins, thereby allowing the transport system to operate more rapidly. The very low GAP activity at zero time probably led to some inaccuracy in determination of kinetic constants, which could explain the higher $K_{\mathrm{T}}$ values obtained for these organisms. Membrane fluidity has previously been invoked to explain differences in kinetics of accumulation of other amino acids by $S$. cerevisiae enriched in linoleyl as compared with oleyl residues (Keenan \& Rose, 1979; Keenan et al., 1982). However, other factors need to be considered to explain the transient twofold difference in $V_{\text {max }}$ value in organisms after $1 \mathrm{~h}$ in derepression buffer. The GAP in $S$. cerevisiae consists of a plasma membrane-bound complex of probably three proteins which effects transmembrane movement of the amino acid, together with a loosely bound periplasmic binding protein (Woodward \& Kornberg, 1980). Our data might indicate that one or more of these proteins are synthesized faster, in the early stages of derepression, when the organism has membranes enriched in linoleyl rather than oleyl residues. Nothing has yet been reported concerning the sites at which GAP proteins are synthesized but, if some of these proteins are synthesized on the plasma membrane, additional phospholipid unsaturation could accelerate their synthesis. A more likely possibility is that some and possibly all GAP proteins are synthesized intracellularly, and transported to the cell envelope in vesicles. This route has been suggested for synthesis of transport systems for sulphate (Novick et al., 1981) and proline (Courchesne \& Magasanik, 1983) in S. cerevisiae. If GAP proteins are also synthesized by this route, the presence of linoleyl rather than oleyl residues in the plasma membranes and vesicles could accelerate fusion of the vesicles with the plasma membrane (Henschke et al., 1983). This suggestion raises the possibility that plasma-membrane phospholipid unsaturation could be a regulatory factor controlling insertion of proteins into the membrane, an idea that is consistent with the views of Ramirez et al. (1983). These workers reported evidence suggesting continued synthesis of plasma-membrane phospholipids but not secreted proteins after transfer of sec mutants (Novick et al., 1981) from the permissive to the restrictive temperature. Since the restrictive temperature $\left(37^{\circ} \mathrm{C}\right)$ was higher than the permissive temperature $\left(24^{\circ} \mathrm{C}\right)$, phospholipids synthesized at the higher temperature would contain proportionately less unsaturation thereby leading to a possible decrease in the affinity of the membrane for protein insertion. Alternatively there is the possibility that one or all of the GAP proteins preferentially locate in more fluid linoleyl residue-enriched regions of the phospholipid bilayer. A transiently greater $V_{\max }$ value could then be explained in terms of more rapid operation of the GAP in these regions. As the number of GAP proteins inserted into the membrane increases, they would be forced to locate into less fluid palmityl residue-enriched regions of the bilayer, thus diluting out the effect of the linoleyl residues on the $V_{\max }$ value. Support for this preferential view of location of transport proteins has come from Hennaut et al. (1970) who reported evidence suggesting that 
specific sites exist in the plasma membrane of $S$. cerevisiae for insertion of L-arginine transport proteins.

We thank the Science and Engineering Research Council (UK) for a research grant (No. GR/B/25728) and for a CASE studentship awarded to J. C. in collaboration with the Brewing Research Foundation, Nutfield, Surrey, England, in association with R. Tubb. We acknowledge advice given by J. R. Woodward, of the Bictechnology Unit, University of Leeds, who also provided the strain of $S$. cerevisiae used in this study. Felicity Veazey of this laboratory gave valuable assistance in the isolation of GAP-less mutants.

\section{REFERENCES}

Alterthum, R. \& Rose, A. H. (1973). Osmotic lysis of sphaeroplasts from Saccharomyces cerevisiae grown anaerobically in media containing different unsaturated fatty acids. Journal of General Microbiology 77 , 371-382.

Andreasen, A. A. \& Stier, T. J. B. (1953). Anaerobic nutrition of Saccharomyces cerevisiae. I. Ergosterol requirement for growth in a defined medium. Journal of Cellular and Comparative Physiology 41, 23-36.

Andreasen, A. A. \& Stier, T. J. B. (1954). Anaerobic nutrition of Saccharomyces cerevisiae. II. Unsaturated fatty acid requirement for growth in a defined medium. Journal of Cellular and Comparative Physio$\log y$ 43, 271-281.

Calderbank, J., Keenan, M. H. J., Rose, A. H. \& Holman, G. D. (1984). Accumulation of amino acids by Saccharomyces cerevisiae Y 185 with phospholipids enriched in different fatty-acyl residues: a statistical analysis of data. Journal of General Microbiology 130, 2817-2824.

Courchesne, W. E. \& Magasanik, B. (1983). Ammonia regulation of amino acid permeases in Saccharomyces cerevisiae. Molecular and Cellular Biology 3, 672-682.

EDDY, A. A. (1982). Mechanisms of solute transport into selected eukaryotic micro-organisms. Advances in Microbial Physiology 23, 1-78.

Elliott, S. G. \& McLaughlin, C. S. (1978). Rate of macromolecular synthesis through the cell cycle of the yeast Saccharomyces cerevisiae. Proceedings of the National Academy of Sciences of the United States of America 75, 4384-4388.

FINK, H. \& KüHLES, R. (1933). Beiträge zur Methylenblaufärburg der Hefezellen und Studien über die Permeabilität der Hefezellmembran. II. Mitteilung. Eine Verbesserte Färbflüssigkeit zur Erkennung von totan Hefezellen. Hoppe Seyler's Zeitschrift für physiologische Chemie 218, 65-66.

Folch, J., Lees, M. \& Sloane Stanley, G. H. (1957). A simple method for the isolation and purification of total lipids from animal tissues. Journal of Biological Chemistry 226, 497-509.

Gregory, M. E., Keenan, M. H. J. \& Rose, A. H. (1982). Accumulation of L-asparagine by Saccharomyces cerevisiae X-2180. Journal of General Microbiology 128, 2557-2562.

Grenson, M. (1983). Study of the positive control of the general amino-acid permease and other ammonia-sensitive uptake systems by the product of the NPR1 gene in the yeast Saccharomyces cerevisiae. European Journal of Biochemistry 133, 141-144.

Grenson, M., Hou, C. \& Crabeel, M. (1970). Multiplicity of the amino acid permeases in Sacchar- omyces cerevisiae. IV. Evidence for a general amino acid permease. Journal of Bacteriology 103, 770-777.

HaRris, G. \& Parsons, R. (1958). Nitrogenous constituents of brewing materials. XI. Nucleic acids of malt and their fate during brewing. Journal of the Institute of Brewing 64, 308-316.

Hennaut, C., Hilger, F. \& Grenson, M. (1970). Space limitation for permease insertion in the cytoplasmic membrane of Saccharomyces cerevisiae. Biochemical and Biophysical Research Communications 39, 666-671.

Henschke, P. A., Thomas, D. S., Rose, A. H. \& Veazey, F. J. (1983). Association of intracellular low-density vesicles with plasma membranes from Saccharomyces cerevisiae NCYC 366. Journal of General Microbiology 129, 2927-2938.

HoFSTEE, B. H. J. (1959). Non-inverted versus inverted plots in enzyme kinetics. Nature, London 184, 12961298.

Keenan, M. H. J. \& Rose, A. H. (1979). Plasmamembrane lipid unsaturation can affect the kinetics of solute accumulation by Saccharomyces cerevisiae. FEMS Microbiology Letters 6, 133-137.

Keenan, M. H. J., Rose, A. H. \& Silverman, B. W. (1982). Effect of plasma membrane phospholipid unsaturation on solute transport into Saccharomyces cerevisiae NCYC 366. Journal of General Microbiology 128, 2547-2556.

KotyK, A. \& Ríhová, L. (1972). Energy requirement for amino acid uptake in Saccharomyces cerevisiae. Folia Microbiologica 17, 353-356.

NEAL, J. L. (1972). Analysis of Michaelis kinetics for two independent saturable membrane transport functions. Journal of Theoretical Biology 35, 113-118.

Novick, P., Ferro, S. \& Schekman, R. (1981). Order of events in the yeast secretory pathway. Cell 25, 461-469.

RAMIREZ, R. M., ISHIDA-SCHICK, T., KRILOWICZ, B. L., Leish, B. A. \& Atkinson, K. D. (1983). Plasma membrane extension terminates in Sacharomyces cerevisiae secretion-defective mutants while phospholipid synthesis continues. Journal of Bacteriology 154, 1276-1283.

Roon, R. J., LARImore, F. \& LeVy, J. S. (1975). Inhibition of amino acid transport by ammonium ions in Saccharomyces cerevisiae. Journal of Bacteriology 124, 325-331.

RytKA, J. (1975). Positive selection of general amino acid permease mutants in Saccharomyces cerevisiae. Journal of Bacteriology 121, 565-570.

Umbreit, W. W., Burris, R. H. \& StalfFer, J. F. (1964). Manometric Techniques (4th edn). Minneapolis: Burgess Publishing Company.

Watson, K. \& Rose, A. H. (1980). Fatty-acyl 
composition of the lipids of Saccharomyces cerevisiae grown aerobically or anaerobically in media containing fatty acids. Journal of General Microbiology 117, 225-233.

Williamson, D. H. (1974). L-Alanine determination with alanine dehydrogenase. In Methods of Enzymatic Analysis (2nd edn), vol. 4, pp. 1679-1682. Edited by H. U. Bergmeyer. New York: Academic Press.
Woodward, J. R. \& Cirillo, V. P. (1977). Amino acid transport and metabolism in nitrogen-starved cells of Saccharomyces cerevisiae. Journal of Bacteriology 130 , 714-723

WOODWARD, J. R. \& KoRnberg, H. L. (1980). Membrane proteins associated with amino acid transport by yeast (Saccharomyces cerevisiae). Biochemical Journal 192, 659-664. 